\title{
SD 0 S COMBRIDGE
}

Review

Author(s): William Miller

Review by: William Miller

Source: The Journal of Hellenic Studies, Vol. 42, Part 1 (1922), pp. 127-128

Published by: The Society for the Promotion of Hellenic Studies

Stable URL: http://www.jstor.org/stable/625955

Accessed: 26-06-2016 23:12 UTC

Your use of the JSTOR archive indicates your acceptance of the Terms \& Conditions of Use, available at

http://about.jstor.org/terms

JSTOR is a not-for-profit service that helps scholars, researchers, and students discover, use, and build upon a wide range of content in a trusted digital archive. We use information technology and tools to increase productivity and facilitate new forms of scholarship. For more information about JSTOR, please contact support@jstor.org.

The Society for the Promotion of Hellenic Studies, Cambridge University Press are collaborating with JSTOR to digitize, preserve and extend access to The Journal of Hellenic Studies 
index, or ${ }^{2} E v \rho \epsilon \tau \eta \dot{p} \rho \iota v$, a reference to any passage there will show every page and column of the lexicon where it is cited. Consequently, though containing more matter, it is less bulky than the earlier issue. Nevertheless it is a volume of considerable size, as the following statistics will show. It contains 24 pages of Introduction, followed by 1283 pages of double columns, $8 \frac{1}{2}$ inches in height by 5 in width, a full column containing 63 lines. It will be admitted that this is a great undertaking for any one man to venture upon, and the author is to be heartily congratulated on having brought his work to a successful conclusion.

As the title implies, his object has not been to compile a complete dictionary of the language - as indeed is plain from the contents of the first page, $\dot{\alpha}^{\alpha} \omega$. $\dot{\alpha} \beta \alpha \kappa \epsilon \in$.

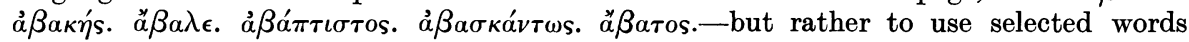
as pegs on which to hang explanations and emendations of passages where he does not agree with the reading or exposition accepted by other scholars. To deal with these at all fully would require a volume rivalling the lexicon itself, but a few may be selected from the examples cited by the author himself in his introduction, and therefore, it may be presumed, those by which he would wish to be judged.

In the following passages he holds that no emendation is needed. Esch. Pers. 815 .

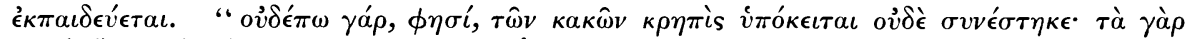

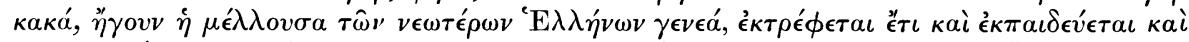

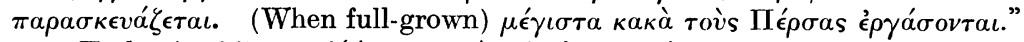

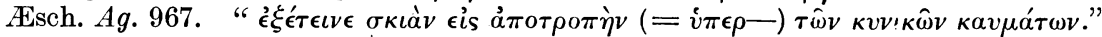

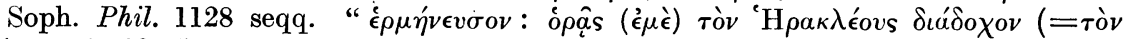

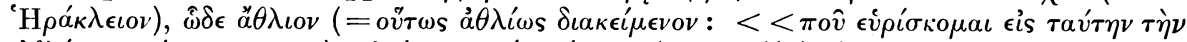

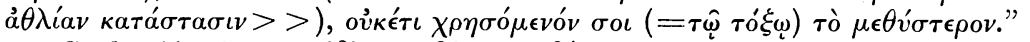

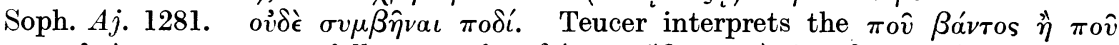

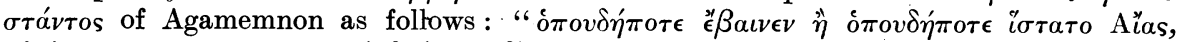

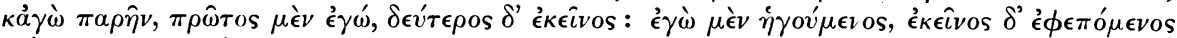

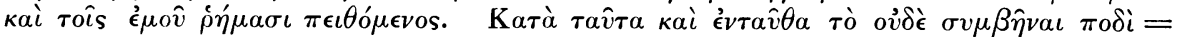

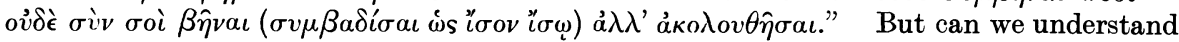

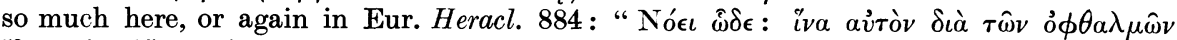

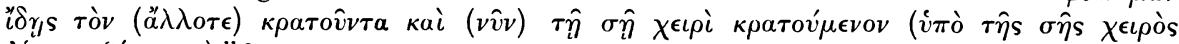

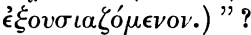

The following passages he would emend :-

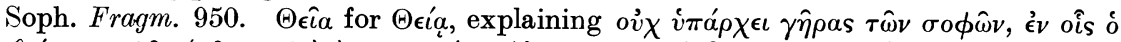

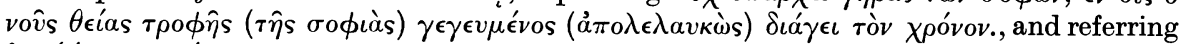

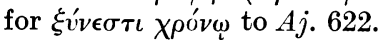

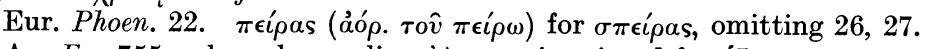

Ar. Eq. 755, where by a slip 'A $\chi \alpha \rho \nu$. is printed for ' $I \pi \pi$. (p. 17). $\epsilon^{\epsilon} \mu \pi \circ \lambda i{ }^{\prime} \zeta \omega \nu$ for

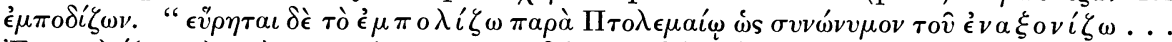

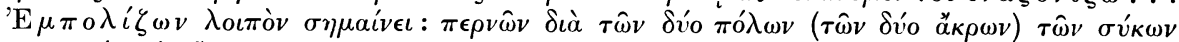

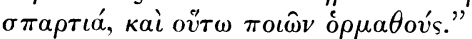

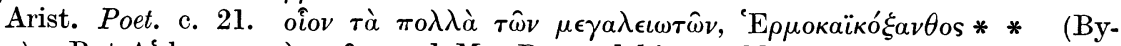
water). But $\mathrm{A}^{c}$ has $\mu \epsilon \gamma \alpha \lambda \iota \omega \tau \omega \nu$, and Mr. Bernardakis would extract from this $\mu \epsilon \operatorname{\epsilon } \gamma \alpha$ $\Delta \hat{\imath}^{\prime} \dot{\alpha} \ddot{v} \tau \hat{\omega} \nu$, writing the whole passage thus: oiov $\tau \grave{\alpha} \pi o \lambda \lambda \grave{\alpha} \tau \hat{\omega} \nu \mathrm{M} \alpha \sigma \sigma \alpha \lambda \iota \omega \tau \hat{\omega} \nu, \mu \epsilon{ }^{\prime} \gamma \nu \nu$

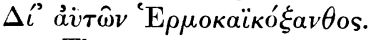

These citations will suffice to show what the author offers to his readers, and it must be left to our leading scholars to decide what can be accepted, and what must be rejected.

Non nostrum . . t tantas componere lites.

H. W. G.

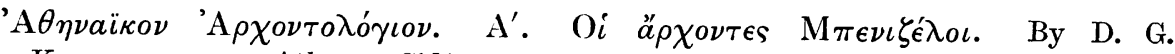 Kampodroglos. Athens : Sidéres, 1921.}

K. Kampoúroglos has long been known as a profound student of Turkish Athens, upon which he has published three volumes of documents and three more of a history, unfortunately not continued after 1687. The present treatise of 208 pages is the first instal- 
ment of a biographical and genealogical account of the Athenian archontic families, which formed the first of the four classes composing Athenian society in Turkish times. Of these families that of the Benizéloi-not to be confounded with the still greater name of the famous Greek statesman of our day-is the most interesting, having produced a considerable number of local celebrities under the Turks. Tradition connects the Benizéloi with the Acciajuoli, the Florentine Dukes of Athens; but the first documentary mention of any member of this, the foremost of the 12 chief archontic families, occurs in the office of the Blessed Philothée, daughter of Angelos Benizélos. This patriarch of the family was born about 1490, and his celebrated daughter, whose remains are still an object of veneration, was martyred by the Turks in 1589 . The Benizéloi produced several prominent teachers, notably Angelos 'the triumphant,' so-called for his victory in a theological discussion, commemorated in the poem of Bouboúles; Demétrios, mentioned by Babin and Spon; and Joánnes, the historian of Athens in the latter half of the eighteenth century. They can boast of an artist, who decorated the monastery of Phaneroméne in Salamis, and their name is commemorated in an inscription of $\mathbf{1 6 8 2}$ in the still more famous monastery of Kaisariané, which was traditionally connected with them and the family of Chalkokondyles, the last Athenian historian of the Middle Ages. In modern times, as English readers will learn with interest, the mother of K. Gennádios, for long Greek Minister in London, was the daughter of a Benizélos. This scholarly little book ends with a genealogical tree of the Benizéloi.

Willitam Miller.

\section{New Chapters in the History of Greek Literature: Recent Discoveries in Greek Poetry and Prose of the Fourth and following Centuries B.C. Edited by J. U. Powell and E. A. Barber. Pp. xi + 166. Oxford: Clarendon Press, 1921. 10s. $6 d$. net.}

The need of such a volume as this, gathering together the results of recent discoveries, has long been felt, and the editors and contributors have earned the gratitude of all students. One may indeed wish-human beings are notoriously an ungrateful race!-that they had widened the scope of their undertaking to include recent additions to Greek literature of all periods; but that would, of course, have meant a much bigger volume, which in these days would have involved heavy expense, and we must be thankful for what we are given, hoping that the editors may some day follow up their gift with a second.

Apart from one or two exceptions, like the appendix to Chapter V, in which a brief description of the farce and mime in P. Oxy. 413 and the mime in Pap. Londin. 1984 is given, the editors have fixed their lower limit of time in the second century B.C.; thus the volume really includes only the sub-classical period of the fourth century B.c., and the Hellenistic period down to the virtual absorption of the Greek world into the Roman Empire. Within these limits of time the editors have cast their net widely, and the volume gives a very complete review of the recent discoveries. It does not aim at furnishing an exhaustive bibliography of the works mentioned, but the principal editions and most impcrtant commentaries are usually referred to, and the character and literary merits (or demerits) of the compositions are indicated.

There is possibly, here and there, a tendency to overrate the importance of the new finds, but that is natural enough in the circumstances, and is certainly better than the excessive depreciation with which some scholars, disappointed in their (often absurdly exaggerated) expectations, have treated them. Perhaps the tendency referred to is most marked in Mr. Lumb's chapter on Menander. That he should emphasise the many merits of that, in his degree, admirable writer, as against the quite unjust strictures of several critics, is all to the good; but he surely exaggerates them in more than one place. In

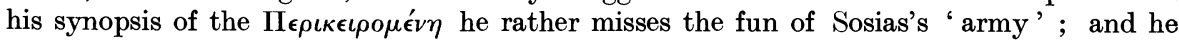
should not speak (p. 91) of the fragments coming ' chiefly from the tombs and earthen vessels of Egypt'; 'ruins and rubbish heaps" would be a better representation of the facts. But these are small points; the chapter is to be welcomed as a salutary corrective to the popular depreciation of Menander. 